\title{
Studi Pembuatan Mie Kering Berbahan Baku Tepung Singkong Dan Mocal (Modified Cassava Flour)
}

\author{
Neny Mariyani \\ Supervisor Jaminan Mutu Pangan, Program Diploma, IPB \\ nenymariyani@gmail.com
}

\begin{abstract}
The objectives of this research is to find the best formulation of cassava flour and mocal (modified cassava flour) based dry noodle which can compete with wheat flour based dry noodle. This research consist of experiments with several variation of composition cassava flour and mocal including $40 \%$ and $50 \%$. Mocal used in this research was produced from spontaneous fermentation which would be compared with commercial mocal which was usually produced from non-spontaneous fermentation. Spontaneous fermentation is natural fermentation process which no added microorganisms. The sensory evaluation of dry and rehydration noodles which are physical appearance, color, odor, taste, gumminess and extensibility. The data was analized by ANOVA (Analysis of Variance) and then Duncan Test. The best result was then examined'for it's chemical composition like moisture content, ash, crude fat, protein and carbohydrate (crude fiber). The result showed that the best formulation to produced dry noodle use mocal from spontaneous fermentation with composition $40 \%$ mocal and $60 \%$ wheat flour. The best dry noodle contained (wet weight basis) of $12,31 \%$ moisture content, 3,97\% ash, 6,69\% protein, 1,13\% crude fat and 3,86\% crude fiber.
\end{abstract}

Keyword : cassava flour, mocal, spontaneous fermentation, commercial mocal

\section{PENDAHULUAN}

Mie merupakan salah satu masakan yang sangat populer di Asia, salah satunya di Indonesia. Sangat disayangkan bahan baku mie yaitu tepung terigu masih $100 \%$ diperoleh dari impor. Indonesia tidak bisa memproduksi sendiri gandum sebagai tumbuhan penghasil tepung terigu, karena iklim yang kurang cocok.

Untuk mengurangi ketergantungan tepung terigu, seharusnya kita mulai mencari bahan baku lokal pengganti tepung terigu yang dapat diolah menjadi produk pangan komersial. Beberapa bahan baku yang telah digunakan sebagai bahan pengganti tepung terigu diantaranya singkong, ubi jalar, tepung beras, shorgum, sagu dan sebagainya. Semua bahan baku pengganti tersebut dalam pengembangannya perlu diperhatikan mengenai alat produksi, ketersediaan bahan baku baik kualitas dan kuantitasnya, serta konsistensi produk dalam skala yang lebih besar.

Singkong (manihot esculenta crantz) merupakan salah satu komoditi pangan lokal yang berpotensi untuk mensubtitusi tepung terigu. Hal ini didukung oleh produktivitas yang tinggi, budidaya yang mudah dan harga yang murah. Beberapa bagian dari singkong yang telah dimanfaatkan untuk dibuat mie diantaranya pati singkong, tepung singkong dan tepung singkong modifikasi (modified cassava flour). Sampai saat ini penelitian-penelitian mengenai formulasi mie dari pati singkong dan tepung singkong sudah banyak dilakukan. Meskipun demikian beberapa hal masih memerlukan kajian lebih lanjut antara lain mengenai formulasinya sehingga diperoleh mie dengan kualitas yang sama atau mendekati mie dengan bahan baku tepung terigu.

Mie basah dengan formulasi tepung singkong dan tepung terigu dengan perbandingan $5: 2$ telah dibuat oleh Pusbangtepa IPB tahun 1989. Mie yang dihasilkan cukup memiliki tekstur yang baik bila diolah dengan benar. Formulasi mie dengan bahan 
baku pati singkong juga telah dilakukan oleh Hidayat (2008), dimana diperoleh hasil formulasi terbaik adalah penggunaan campuran pati singkong dan tepung terigu dengan perbandingan $3: 2$.

Hasil penelitian Abidin (2009) menunjukkan formulasi mie basah dengan komposisi bahan baku yang terdiri atas campuran tepung singkong (yang sudah melalui proses fermentasi) dan tepung terigu dengan perbandingan $5: 1$, telur, gluten, garam, air abu, air, dan minyak goreng serta diproses secara bertahap, menunjukkan mie basah tersebut memiliki kemiripan sebesar $80 \%$ terhadap mie tepung terigu. Beberapa kelemahan dari tepung singkong adalah warnanya putih agak kecoklatan dan rasa serta aromanya masih terkesan singkong. Untuk mengatasi masalah tersebut kini sedang dikembangkan penggunaan mocal atau mocaf. Mocal atau modified cassava flour adalah tepung singkong yang telah mengalami proses fermentasi.

Mocal adalah produk tepung dari singkong yang diproses menggunakan prinsip memodifikasi sel singkong secara fermentasi dimana selama proses itu berlangsung didominasi oleh Bakteri Asam Laktat (BAL) (Subagio 2009). Mikroba yang tumbuh menghasilkan enzim pektinolitik dan selulolitik (enzim yang bisa memecah pectin dan selulosa) yang dapat menghancurkan dinding sel singkong, sehingga terjadi liberalisasi granula pati. Mikroba tersebut juga menghasilkan enzim-enzim yang menghidrolisis pati menjadi gula dan selanjutnya mengubahnya menjadi asam-asam organik, terutama asam laktat. Hal ini menyebabkan perubahan karakteristik dari tepung yang dihasilkan berupa naiknya viskositas, kemampuan gelasi, daya rehidrasi dan kemudahan melarut. Demikian pula cita rasa mocal menjadi netral menutupi cita rasa singkong sampai $70 \%$. Pada Tabel 1 berikut dapat dilihat perbedaan sifat organoleptik, sifat fisik dan sifat kimia mocal dengan tepung singkong (Anonim, 2009).

Melihat potensi penggunaan mocal di atas maka terdapat peluang yang cukup besar untuk diterapkan pada pembuatan mie kering, selain pemanfaatan dari pati singkong maupun tepung singkongnya. Diperkirakan di masa mendatang penggunaan mie akan semakin meluas karena sifat penggunaannya yang praktis, mudah dan rasanya disukai.

Pada penelitian ini akan dibuat mie kering berbahan baku tepung singkong dan mocal (baik yang dibuat dari fermentasi spontan maupun mocal komersial, yakni dengan penambahan kultur starter atau fermentasi non spontan), dengan kontrol mie kering berbahan baku tepung terigu $100 \%$. Diharapkan dapat diperoleh formulasi terbaik dari tepung singkong atau mocal yang secara organoleptik dapat diterima seperti halnya mie kering dari tepung terigu. Penelitian ini bertujuan untuk menentukan formulasi bahan baku pembuatan mie kering dari tepung singkong dan mocal dengan kualitas yang mampu bersaing dengan produk serupa dari tepung terigu. 
Tabel 1. Perbedaan sifat organoleptik, sifat fisik dan sifat kimia mocal dengan tepung singkong $\left.{ }^{\star}\right)$

\begin{tabular}{llll}
\hline No & \multicolumn{1}{c}{ Parameter } & \multicolumn{1}{c}{ Mocal } & \multicolumn{1}{c}{ tepung singkong } \\
\hline 1 & Komposisi kimia & Maks. 13 & Maks. 13 \\
& Kadar air (\%) & Maks. 1,0 & Maks. 1,2 \\
& Kadar abu (\%) & Maks. 0,2 & Maks. 0,2 \\
& Kadar protein (\%) & $85-87$ & $82-85$ \\
& Kadar pati (\%) & $1,9-3,4$ & $1,0-4,2$ \\
& Kadar lemak (\%) & $0,4-0,8$ & $0,4-0,8$ \\
& Kadar serat (\%) & Tidak terdeteksi & Tidak terdeteksi \\
& Kadar HCN (mg/kg) & & \\
& Sifat fisik & Maks. 80 & Maks. 80 \\
& Besar butiran (mesh) & $88-91$ & $85-87$ \\
& Derajat keputihan (\%) & $52-55(2 \%$ pasta panas) & $20-40(2 \%$ pasta panas) \\
& Kekentalan (mPa.s) & $75-77(2 \%$ pasta dingin) & $30-50(2 \%$ pasta dingin) \\
& & & \\
3 & Sifat organoleptik & Putih & Putih agak kecoklatan \\
& Warna & Netral & Kesan singkong \\
& Aroma & Netral & Kesan singkong \\
& Rasa & &
\end{tabular}

*) Anonim, 2009

\section{METODOLOGI}

Bahan yang digunakan dalam penelitian ini meliputi bahan baku dan bahan tambahan. Bahan baku yang digunakan terdiri dari tepung singkong, mocal dari fermentasi spontan, mocal komersial dan tepung terigu. Sedangkan bahan tambahan diantaranya: air abu atau garam alkali yakni campuran natrium karbonat $\left(\mathrm{Na}_{2} \mathrm{CO}_{3}\right)$ dan kalium karbonat $\left(\mathrm{K}_{2} \mathrm{CO}_{3}\right.$ ), garam, air, CMC (Carboxy Metyl Cellulose), sodium tri poli pospat (STPP) dan minyak goreng.

Alat-alat yang diperlukan terdiri dari timbangan, alat pengayak tepung, blender, saringan, oven, alat penggiling, alat pemotong mie, kompor, tampah, baskom plastik, dandang, parutan chip dan panci. Bahan-bahan untuk peralatan dibuat dari bahan yang memenuhi standar food grade.

Tahapan-tahapan studi yang dilakukan dalam penelitian ini yaitu:

a. Tahap penelitian pendahuluan meliputi (i) percobaan pembuatan tepung singkong dan mocal secara fermentasi spontan skala laboratorium dan (ii) percobaaan pembuatan formula standar mie kering. Diagram alir pembuatan tepung singkong dan mocal dengan fermentasi spontan dapat dilihat pada Gambar 1. Sedangkan pada Gambar 2 dapat dilihat diagram alir pembuatan mie kering berbahan baku tepung terigu, tepung singkong dan mocal.

b. Tahap pembuatan mie kering tepung singkong dan mocal dengan berbagai variasi. Susunan perlakuan yang digunakan pada pengembangan formulasi produk mie kering dari tepung singkong dan mocal dapat dilihat pada Tabel 2. Tabel 3 merupakan formula standar pembuatan mie kering dari tepung terigu, sedangkan Tabel 4 merupakan Formula standar pembuatan mie kering dari tepung singkong dan mocal. 
Tabel 2. Deskripsi variasi percobaan

\begin{tabular}{ll}
\hline \multicolumn{1}{c}{ Jenis Variasi } & \multicolumn{1}{c}{ Sub-Variasi } \\
\hline $\mathrm{A}=$ Produk mie kering dari tepung singkong & A.1. Tepung singkong $40 \%$ \\
& A.2. Tepung singkong $50 \%$ \\
$\mathrm{~B}=$ Produk mie kering dari mocal & B.1. Mocal (S) $40 \%$ \\
(dengan fermentasi spontan) & B.2. Mocal (S) $50 \%$ \\
$\mathrm{C}=$ Produk mie kering dari mocal (komersial) & C.1. Mocal (K) $40 \%$ \\
$\mathrm{D}=$ Produk mie kering dari tepung terigu & D.1. Tepung terigu $100 \%$ \\
\hline
\end{tabular}

c. Tahap pengujian organoleptik terhadap mie dengan formulasi terbaik

Hasil mie dari setiap variasi yang dilakukan pada penelitian sebelumnya, kemudian diujikan kepada beberapa panelis ( \pm 30 orang panelis), yaitu mahasiswa, dosen, laboran, dan karyawan. Hal ini dimaksudkan untuk mendapatkan data sebagai dasar pemilihan produk optimum. Jenis uji yang dilakukan yaitu uji perbandingan jamak dan uji hedonik. Mie disajikan dalam bentuk mie kering dan mie rehidrasi (mie kering yang sudah direbus).

Uji perbandingan jamak dimaksudkan untuk mengetahui bagaimana atribut mutu (rasa, warna, penampakan, aroma, kekenyalan dan ekstensibilitas) dari mie yang terbuat dari tepung singkong dan mocal jika dibandingkan dengan mie dari tepung terigu $100 \%$ (kontrol). Sedangkan uji hedonik dilakukan untuk mengetahui tingkat kesukaan panelis terhadap semua atribut mutu untuk masing-masing formula mie.

Selain kedua uji tersebut dilakukan pengujian oleh panelis untuk menilai urutan atribut mutu terhadap mie rehidrasi mulai dari yang paling penting hingga kurang penting. Uji ini ditujukan untuk melihat bagaimana penerimaan panelis terhadap atribut mutu apa yang menurut mereka paling penting dari mie rehidrasi yang diujikan.

Data hasil uji hedonik dianalisis dengan uji sidik ragam (ANOVA) dan uji lanjutan Duncan, sedangkan untuk uji perbandingan jamak dilihat nilai rata-ratanya dibandingkan dengan kontrol. Untuk menilai urutan atribut mutu dari yang paling penting, dilihat nilai frekuensi dari masing-masing atribut mutu.

d. Tahap pengujian komposisi kimiawi mie kering singkong

Analisis komposisi kimiawi pada mie kering singkong terpilih dilakukan terhadap parameter kadar air (metode oven), abu, protein (metode Mikro Kjeldahl), lemak kasar (metode Soxhlet) dan serat kasar (metode Van Soest).

\section{HASIL DAN PEMBAHASAN}

Tepung singkong yang dihasilkan memiliki rendemen $\pm 30 \%$. Tepung singkong memiliki aroma khas singkong, berwarna putih agak kecoklatan dan rasanya terkesan singkong. Warna tepung singkong yang berwarna putih agak kecoklatan kemungkinan disebabkan perubahan cuaca saat dilakukan pengeringan secara alami. Intensitas panas dari sinar matahari yang dikenakan pada produk tidak selalu sama setiap harinya.

Pembuatan mocal skala laboratorium dilakukan dengan cara fermentasi spontan. Fermentasi spontan yaitu proses fermentasi yang berlangsung dengan sendirinya tanpa penambahan starter mikroba. Mocal yang dihasilkan memiliki rendemen $\pm 30 \%$, aroma dan rasa yang netral, serta berwarna putih, bahkan melebihi warna putih dari tepung terigu. 
Air perendam potongan singkong dalam pembuatan mocal, setelah diujikan pada media spesifik untuk bakteri dari golongan Bakteri Asam Laktat (BAL), yakni media MRSB (de man, Rogosa, Sharpe Broth) dan MRSA, diperoleh hasil positif pada masingmasing media berupa kekeruhan dan pertumbuhan koloni yang terpisah. Hal ini menunjukkan telah terjadi fermentasi spontan, dimana dengan adanya substrat singkong, bakteri tumbuh dengan sendirinya, tanpa perlu penambahan kultur starter.

Tabel 3. Formula standar pembuatan mie kering dari tepung terigu

\begin{tabular}{llc}
\hline No & \multicolumn{1}{c}{ Nama Bahan } & Prosentase $(\%)$ \\
\hline 1 & Tepung terigu & 100 \\
2 & Garam & 2 \\
3 & CMC & 0,2 \\
4 & Natrium karbonat $\left(\mathrm{Na}_{2} \mathrm{CO}_{3}\right)$ & 0,3 \\
5 & Kalium karbonat $\left(\mathrm{K}_{2} \mathrm{CO}_{3}\right)$, & 0,5 \\
6 & STTP & 0,25 \\
7 & Air & 50 \\
\hline
\end{tabular}

Tabel 3 dan 4 berturut-turut menyajikan formula standar pembuatan mie kering dari tepung terigu dan formula standar pembuatan mie kering dari tepung singkong dan mocal. Dari Tabel tersebut dapat dilihat komposisi untuk semua bahan tambahan (garam, CMC, natrium karbonat, kalium karbonat STTP dan air) tetap sama. Perbedaan hanya terletak pada komposisi bahan baku yang digunakan. Pada Tabel 4 , jika tepung singkong yang digunakan sebanyak $40 \%$, maka tepung terigu yang ditambahkan $60 \%$, jika tepung singkong yang digunakan $50 \%$, maka tepung terigu yang digunakan $50 \%$, begitu pula halnya dengan mocal.

Tabel 4. Formula standar pembuatan mie kering dari tepung singkong dan mocal

\begin{tabular}{llc}
\hline No & \multicolumn{1}{c}{ Nama Bahan } & Prosentase $(\%)$ \\
\hline 1 & Tepung singkong/ mocal & 40 atau 50 \\
2 & Tepung terigu & 60 atau 50 \\
2 & Garam & 2 \\
3 & CMC & 0,2 \\
4 & Natrium karbonat $\left(\mathrm{Na}_{2} \mathrm{CO}_{3}\right)$ & 0,3 \\
5 & Kalium karbonat $\left(\mathrm{K}_{2} \mathrm{CO}_{3}\right)$, & 0,5 \\
6 & STTP & 0,25 \\
7 & Air & 50 \\
\hline
\end{tabular}

Garam alkali yang digunakan merupakan campuran natrium/sodium karbonat $\left(\mathrm{Na}_{2} \mathrm{CO}_{3}\right)$ yang lebih dikenal dengan nama soda abu, dan kalium/potasium karbonat $\left(\mathrm{K}_{2} \mathrm{CO}_{3}\right)$. Fungsi penambahan garam alkali pada pembuatan mie adalah : menguatkan struktur gluten sehingga menjadi mie yang lentur, mengubah sifat mie pati tepung terigu sehingga mie menjadi lebih kenyal dan mengubah sifat zat warna (pigmen) dalam terigu sehingga lebih cerah (Suyanti, 2010). Semakin besar garam alkali yang digunakan, mie semakin keras dan kenyal. Namun penggunaan yang berlebihan akan menyebabkan bau yang tidak sedap pada mie yang dihasilkan Batas maksimum garam alkali yang ditambahkan pada pembuatan mie adalah $1 \%$ dari total pemakaian tepung terigu yang digunakan.

Garam berfungsi untuk memberi rasa, meningkatkan konsistensi adonan (fleksibilitas dan elastisitas mie). Selain itu penambahan garam dapat menghambat Neny Mariyani 
pertumbuhan jamur/kapang serta menghambat aktivitas enzim protease dan amilase sehingga adonan menjadi tidak lengket dan mengembang secara berlebihan.
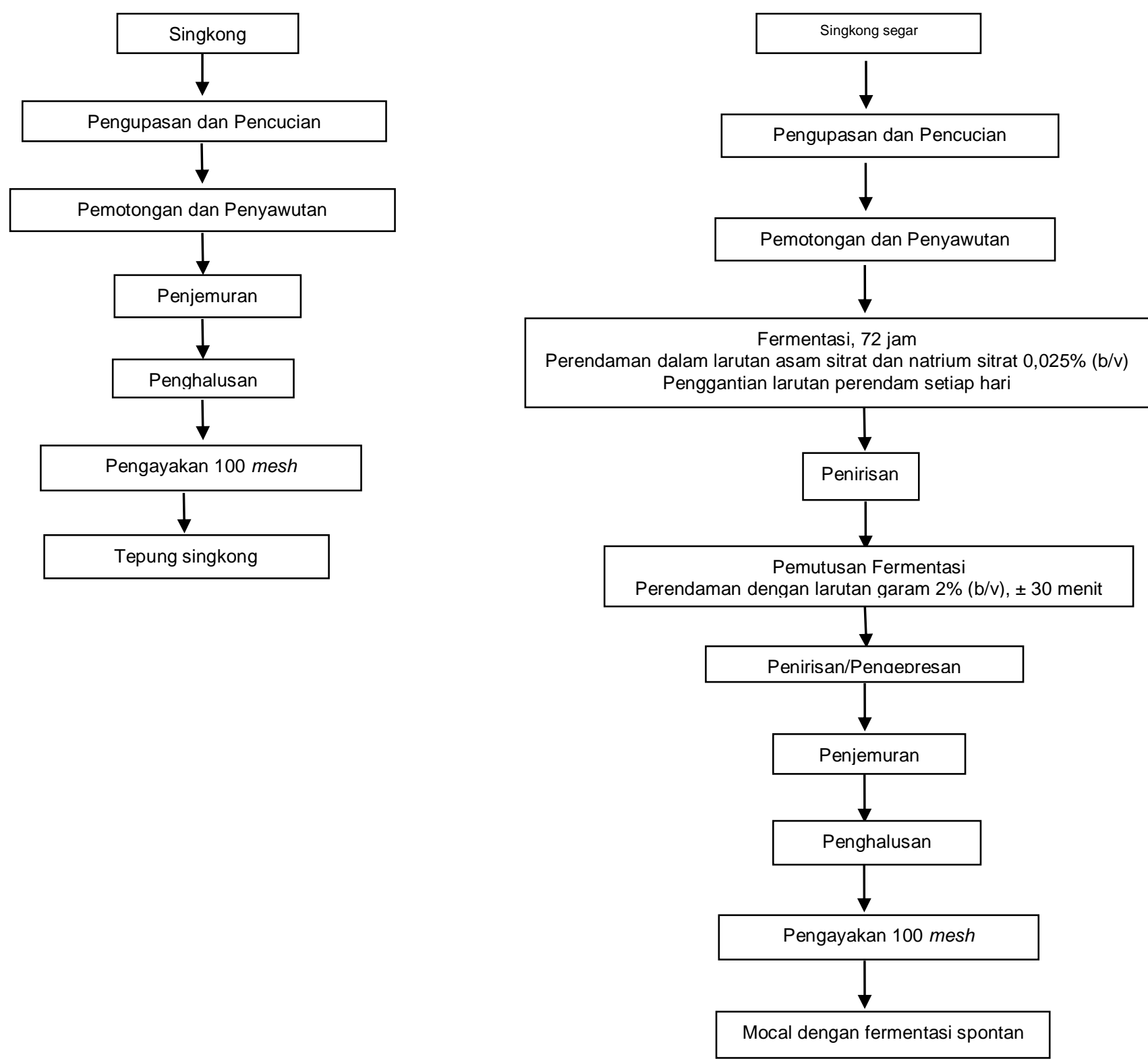

Gambar 1. Diagram alir pembuatan tepung singkong dan mocal dengan fermentasi spontan 


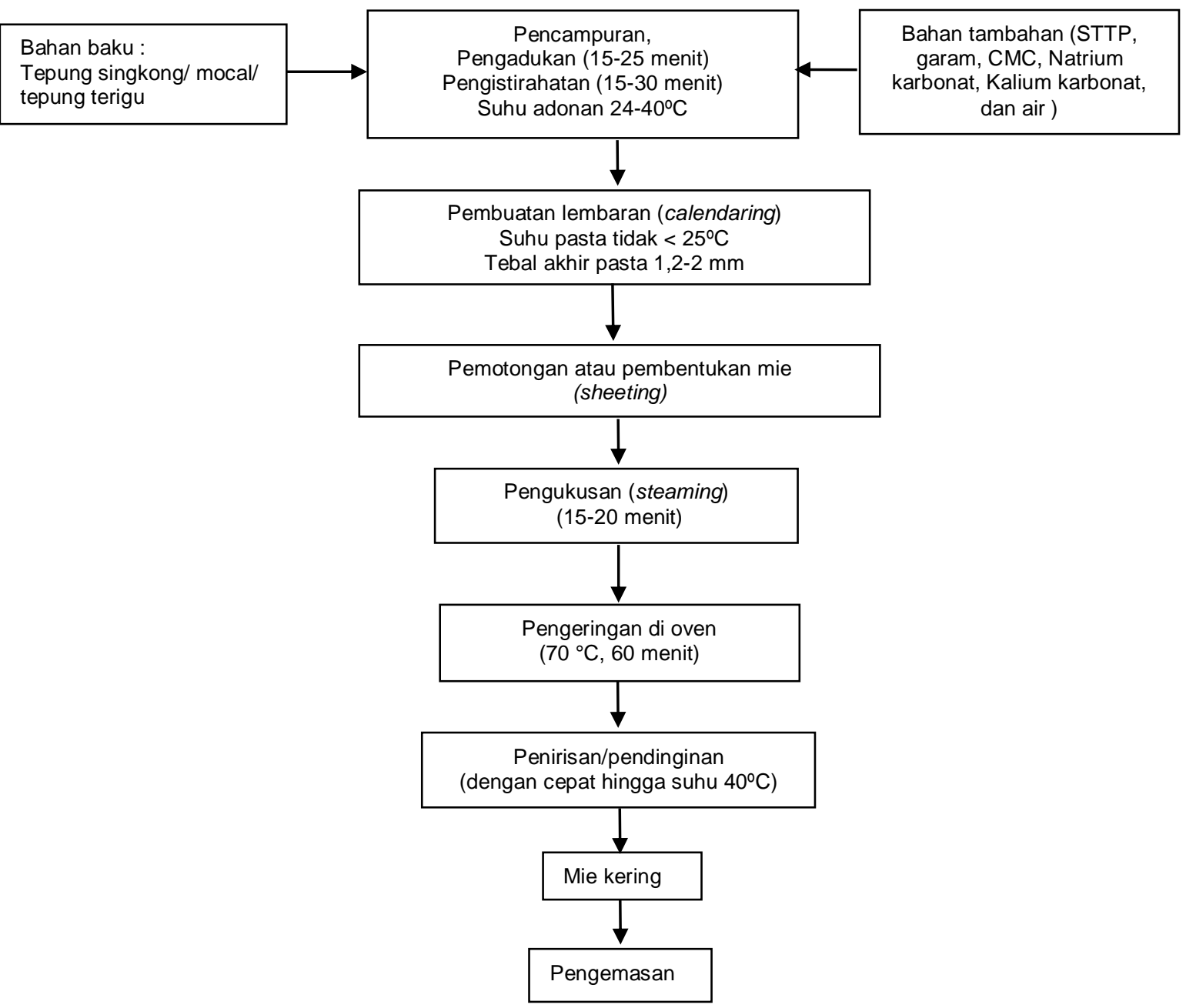

Gambar 2. Diagram alir pembuatan mie kering berbahan baku tepung terigu, tepung singkong atau mocal

Air berfungsi sebagai media reaksi antara gluten dengan karbohidrat, melarutkan garam dan membentuk sifat kenyal. Penambahan air yang terlalu sedikit akan membuat adonan sulit dicetak, sedangkan penambahan air yang terlalu banyak akan menyebabkan adonan mie lengket.

CMC berfungsi sebagai stabilizer yang mengendalikan berpindahnya air dalam adonan mie pada saat dimasak, sehingga adonan mie menjadi kompak dan tidak mudah hancur. CMC juga berfungsi untuk mencegah terjadinya sinerisis, yakni pecahnya gel akibat perubahan suhu. STTP mempengaruhi kekenyalan dan kelenturan mie. Sedangkan minyak goreng ditambahkan untuk mencegah perlengketan antar potongan mie.

Hasil yang diperoleh mie kering dari tepung singkong warnanya lebih gelap (kurang cerah) dibandingkan dengan kontrolnya (mie kering dari tepung terigu $100 \%$ ). Hal ini sudah bisa diprediksi dari warna tepung singkong yang digunakan, yakni berwarna kecoklatan. Selain itu penggunaan oven yang tidak memiliki kontrol suhu sangat berpengaruh terhadap warna mie kering yang dihasilkan.

Terdapat perbedaan antara tepung singkong dan tepung terigu, diantaranya tepung singkong tidak mengandung gluten. Gluten adalah senyawa protein pada tepung 
terigu yang memberikan elastisitas dan ekstensibilitas pada mie. Hal ini mengakibatkan mie yang terbuat dari tepung singkong kurang kuat dan elastis.

Selain itu dalam singkong terkandung senyawa yang berpotensi racun yaitu linamarin dan lotaustralin yang keduanya termasuk golongan glikosida sianogenik. Singkong dibedakan atas dua tipe yaitu pahit dan manis. Singkong tipe pahit mengandung kadar racun yang lebih tinggi daripada tipe manis. Jika singkong mentah atau yang dimasak kurang sempurna dikonsumsi, maka racun tersebut akan berubah menjadi senyawa kimia yang dinamakan hidrogen sianida yang dapat menimbulkan gangguan kesehatan. Pembuatan mocal secara spontan yakni dengan perendaman dalam larutan ber $\mathrm{pH} 4$ (campuran asam sitrat dan natrium sitrat 0,025\%) selama 3 hari, diharapkan dapat menurunkan kadar HCN dalam singkong, sehingga tepung mocal yang dihasilkan dapat dijadikan bahan baku dalam pembuatan mie kering dengan kadar HCN seminimal mungkin atau bahkan tidak terdeteksi, sehingga aman untuk dikonsumsi oleh tubuh.

Mie kering yang terbuat dari mocal (spontan) $40 \%$ dan $50 \%$ warnanya mendekati mie kering dari tepung terigu $100 \%$. Tepung singkong yang telah melalui proses fermentasi (mocal) mampu menghilangkan rasa asli dari singkong itu sendiri, sehingga pada aplikasinya mie yang dihasilkan dapat lebih menyerupai mie dari tepung terigu.

Warna mie kering dari mocal komersial paling gelap diantara semua mie kering. Hal ini kemungkinan besar disebabkan kualitas mocal (komersialnya) sendiri sudah kurang bagus ketika diterima, diantaranya warnanya yang lebih gelap dibandingkan mocal dengan fermentasi spontan. Tetapi dari segi aroma, tidak tercium lagi aroma singkong dari mie kering yang dihasilkan.

Uji organoleptik yang dilakukan terdiri dari uji perbandingan jamak dan uji hedonik. Sebanyak \pm 30 orang panelis menilai atribut mutu seperti penam-pakan, aroma, warna, rasa, kekenyalan dan ekstensibilitas (mudah atau tidak mie tersebut putus setelah diregangkan oleh tangan) pada semua produk mie kering dan atau mie rehidrasi (mie kering yang sudah direbus).

Pada uji perbandingan jamak untuk mie kering, hasil pengujian menun-jukkan bahwa hanya mie kering berbahan baku mocal (spontan) $40 \%$ memiliki nilai rata-rata untuk setiap parameter uji diatas 0 yakni nilai rata-rata untuk aroma, penampakan dan warna berturut-turut adalah 0,$47 ; 1,20$; dan 0,80 . Nilai 0 menun-jukkan sama dengan kontrol mie kering dari tepung terigu $100 \%$. Hal ini menunjukkan mie kering ini dari segi aroma, penampakan dan warna nilainya lebih baik dibandingkan mie kering dari tepung terigu $100 \%$. Rata-rata hasil uji perbandingan jamak untuk mie kering dapat dilihat pada Tabel 5.

Tabel 5. Rata-rata hasil uji perbandingan jamak mie kering

\begin{tabular}{lcccccc}
\hline \multirow{3}{*}{ Atribut mutu } & $\begin{array}{c}\text { Mocal } \\
(\mathrm{K})\end{array}$ & $\begin{array}{c}\text { Tepung } \\
\text { Singkong }\end{array}$ & $\begin{array}{c}\text { Tepung } \\
\text { Singkong }\end{array}$ & $\begin{array}{c}\text { Mocal } \\
(\mathrm{S})\end{array}$ & $\begin{array}{c}\text { Tepung } \\
\text { Terigu }\end{array}$ & $\begin{array}{c}\text { Mocal } \\
(\mathrm{S})\end{array}$ \\
& $40 \%$ & $50 \%$ & $40 \%$ & $50 \%$ & $100 \%$ & $40 \%$ \\
\hline Aroma & $-0,37$ & $-0,50$ & $-0,17$ & $-0,07$ & 0,00 & 0,47 \\
Penampakan & $-1,57$ & $-0,50$ & $-0,53$ & $-0,37$ & 0,00 & 1,20 \\
Warna & $-2,13$ & $-0,67$ & $-1,03$ & $-0,30$ & 0,00 & 0,80 \\
\hline
\end{tabular}

Pada uji perbandingan jamak untuk sampel mie rehidrasi, panelis membandingkan warna, aroma, rasa, kekenyalan, dan ekstensibilitas dari mie rehidrasi yang tersaji dengan contoh pembanding. Hasil pengujian menunjukkan bahwa hanya mie rehidrasi dari mocal spontan (S) $40 \%$ yang memiliki nilai rata-rata untuk setiap parameter 
uji di atas 0 . Nilai rata-rata untuk aroma, ekstensibilitas, kekenyalan, rasa dan warna berturut-turut adalah 0,$30 ; 0,40 ; 0,67 ; 0,73$; dan 1,33 . Hal ini menunjukkan mie ini dari warna, aroma, rasa, kekenyalan, dan ekstensibilitas nilainya lebih baik dibandingkan mie rehidrasi dari tepung terigu $100 \%$. Rata-rata hasil uji perbandingan jamak untuk sampel mie rehidrasi dapat dilihat pada Tabel 6 .

Tabel 6. Rata-rata hasil uji perbandingan jamak mie rehidrasi

\begin{tabular}{lcccccc}
\hline Atribut mutu & $\begin{array}{c}\text { Mocal } \\
(\mathrm{K}) 40 \%\end{array}$ & $\begin{array}{c}\text { Tepung } \\
\text { Singkong } \\
50 \%\end{array}$ & $\begin{array}{c}\text { Tepung } \\
\text { Singkong } \\
40 \%\end{array}$ & $\begin{array}{c}\text { Mocal } \\
(\mathrm{S}) 50 \%\end{array}$ & $\begin{array}{c}\text { Tepung } \\
\text { Terigu } \\
100 \%\end{array}$ & $\begin{array}{c}\text { Mocal } \\
(\mathrm{S}) 40 \%\end{array}$ \\
\hline Aroma & $-0,50$ & $-1,00$ & $-0,33$ & 0,13 & 0,00 & 0,30 \\
Ekstensibilitas & 0,10 & $-1,33$ & $-0,67$ & $-0,40$ & 0,00 & 0,40 \\
Kekenyalan & $-0,67$ & $-0,70$ & $-0,47$ & 0,23 & 0,00 & 0,67 \\
Rasa & $-0,77$ & $-0,37$ & $-0,43$ & 0,57 & 0,00 & 0,73 \\
Warna & $-1,13$ & $-0,87$ & $-0,50$ & 0,10 & 0,00 & 1,33 \\
\hline
\end{tabular}

Hasil pengujian organoleptik terhadap aroma mie kering menunjukkan bahwa mie kering berbahan baku mocal (S) 40\% dari segi aroma tidak berbeda nyata dengan mie kering dari tepung terigu $100 \%$. Nilai rata-rata kesukaan panelis terhadap aroma mie kering berbahan baku mocal (S) 40\% $(4,8857)$ sedikit di atas mie kering dari tepung terigu $100 \%(4,4286)$ artinya panelis lebih menyukai aroma mie kering berbahan baku mocal (S) 40\%. Rata-rata hasil uji hedonik pada mie kering dapat dilihat pada Tabel 7.

Hasil pengujian organoleptik terhadap penampakan mie kering menunjukkan bahwa mie kering berbahan baku mocal (S) $40 \%$ dari segi penampakan tidak berbeda nyata dengan mie kering dari tepung terigu $100 \%$. Nilai rata-rata kesukaan panelis terhadap penampakan mie kering berbahan baku mocal (S) $40 \%(5,6571)$ sedikit di atas mie kering dari tepung terigu $100 \%(5,3824)$, artinya panelis lebih menyukai penampakan sampel mie kering berbahan baku mocal (S) $40 \%$.

Tabel 7. Rata-rata hasil uji hedonik mie kering

\begin{tabular}{lcccccc}
\hline Atribut mutu & $\begin{array}{c}\text { Mocal (K) } \\
40 \%\end{array}$ & $\begin{array}{c}\text { Tepung } \\
\text { Singkong } \\
50 \%\end{array}$ & $\begin{array}{c}\text { Tepung } \\
\text { Singkong } \\
40 \%\end{array}$ & $\begin{array}{c}\text { Mocal (S) } \\
50 \%\end{array}$ & $\begin{array}{c}\text { Tepung } \\
\text { Terigu } \\
100 \%\end{array}$ & $\begin{array}{c}\text { Mocal } \\
(\mathrm{S}) 40 \%\end{array}$ \\
\hline Aroma & $3,7143^{\mathrm{a}}$ & $3,9143^{\mathrm{ab}}$ & $4,1714^{\mathrm{ab}}$ & $4,4000^{\mathrm{abc}}$ & $4,4286^{\mathrm{bc}}$ & $4,8857^{\mathrm{c}}$ \\
Penampakan & $2,4286^{\mathrm{a}}$ & $3,2286^{\mathrm{b}}$ & $3,5714^{\mathrm{b}}$ & $4,5429^{\mathrm{c}}$ & $5,3824^{\mathrm{d}}$ & $5,6571^{\mathrm{d}}$ \\
Warna & $2,0000^{\mathrm{a}}$ & $3,2286^{\mathrm{b}}$ & $3,5714^{\mathrm{b}}$ & $4,2571^{\mathrm{c}}$ & $5,3714^{d}$ & $5,7429^{d}$ \\
\hline
\end{tabular}

Ket : Angka-angka yang ditandai dengan huruf yang sama, tidak berbeda nyata menurut uji Duncan $(\alpha=0,05)$

Hasil pengujian organoleptik terhadap warna mie kering menunjukkan bahwa mie kering berbahan baku mocal (S) $40 \%$ dari segi warna tidak berbeda nyata dengan mie kering dari tepung terigu $100 \%$. Nilai rata-rata kesukaan panelis terhadap warna mie kering berbahan baku mocal (S) 40\% $(5,7429)$ sedikit di atas mie kering dari tepung terigu $100 \%(5,3714)$, artinya panelis lebih menyukai warna sampel mie kering berbahan baku mocal (S) $40 \%$. 
Tabel 8. Rata-rata hasil uji hedonik mie rehidrasi

\begin{tabular}{|c|c|c|c|c|c|c|}
\hline Atribut mutu & $\begin{array}{c}\text { Mocal }(\mathrm{K}) \\
40 \%\end{array}$ & $\begin{array}{c}\text { Tepung } \\
\text { Singkong } \\
50 \%\end{array}$ & $\begin{array}{c}\text { Tepung } \\
\text { Singkong } \\
40 \%\end{array}$ & $\begin{array}{c}\text { Mocal (S) } \\
50 \%\end{array}$ & $\begin{array}{c}\text { Tepung } \\
\text { Terigu } \\
100 \%\end{array}$ & $\begin{array}{c}\text { Mocal } \\
\text { (S) } 40 \%\end{array}$ \\
\hline Aroma & $3,0606^{a}$ & $3,0606^{a}$ & $3,8182^{b}$ & $3,8788^{b}$ & $4,5152^{b}$ & $4,0303^{b}$ \\
\hline Ekstensibilitas & $4,1212^{b c}$ & $2,6970^{a}$ & $3,8788^{b c}$ & $3,4848^{b}$ & $4,3939^{c}$ & $4,3636^{c}$ \\
\hline Kekenyalan & $4,0000^{b}$ & $3,1515^{a}$ & $4,0000^{b}$ & $4,1212^{c}$ & $4,7273^{c}$ & $4,7879^{c}$ \\
\hline Rasa & $3,1818^{a}$ & $3,3939^{a b}$ & $4,0606^{b c}$ & $3,9697^{b c}$ & $4,0303^{b c}$ & $4,4848^{c}$ \\
\hline Warna & $2,2121^{a}$ & $2,9394^{\mathrm{b}}$ & $4,4242^{c d}$ & $4,1818^{c}$ & $5,0303^{\text {de }}$ & $5,2424^{e}$ \\
\hline
\end{tabular}

Pada Tabel 8 dapat dilihat rata-rata hasil uji hedonik terhadap mie rehidrasi. Berdasarkan hasil pengujian organoleptik terhadap aroma mie rehidrasi menunjukkan bahwa mie rehidrasi dari mocal (S) 40\%, mocal (S) 50\% dan tepung singkong $40 \%$ dari segi aroma tidak berbeda nyata dengan mie rehidrasi dari tepung terigu $100 \%$. Nilai ratarata kesukaan panelis terhadap aroma mie rehidrasi berbahan baku mocal (S) $40 \%$ $(4,0303)$ sedikit di bawah mie rehidrasi dari tepung terigu 100\% $(4,5152)$.

Berdasarkan hasil pengujian organoleptik terhadap ekstensibilitas mie rehidrasi menunjukkan bahwa mie rehidrasi dari mocal (S) 40 dari segi ekstensibilitas tidak berbeda nyata dengan mie rehidrasi dari tepung terigu $100 \%$. Nilai rata-rata kesukaan panelis terhadap aroma mie rehidrasi berbahan baku mocal (S) $40 \%(4,3636)$ sedikit di bawah mie rehidrasi dari tepung terigu $100 \%(4,3939)$.

Berdasarkan hasil pengujian organoleptik terhadap kekenyalan mie rehidrasi menunjukkan bahwa mie rehidrasi dari mocal (S) $40 \%$ dan mocal (S) $50 \%$ dari segi kekenyalan tidak berbeda nyata dengan mie rehidrasi dari tepung terigu $100 \%$. Nilai ratarata kesukaan panelis terhadap kekenyalan mie rehidrasi berbahan baku mocal (S) $40 \%$ $(4,7879)$ sedikit di atas mie rehidrasi dari tepung terigu $100 \%(4,3939)$, ini artinya panelis lebih menyukai kekenyalan mie kering berbahan baku mocal (S) $40 \%$.

Berdasarkan hasil pengujian organoleptik terhadap rasa mie rehidrasi menunjukkan bahwa mie rehidrasi dari mocal (S) $40 \%$ dari segi rasa tidak berbeda nyata dengan mie rehidrasi dari tepung terigu $100 \%$. Nilai rata-rata kesukaan panelis terhada rasa mie rehidrasi berbahan baku mocal (S) $40 \%(4,4848)$ sedikit di atas mie rehidrasi dari tepung terigu $100 \%(4,0303)$, ini artinya panelis lebih menyukai rasa mie kering berbahan baku mocal (S) $40 \%$.

Hasil pengujian organoleptik terhadap warna mie rehidrasi menunjukkan bahwa mie rehidrasi dari mocal (S) $40 \%$ dari segi warna tidak berbeda nyata dengan mie rehidrasi dari tepung terigu $100 \%$. Nilai rata-rata kesukaan panelis terhada warna mie rehidrasi berbahan baku mocal (S) $40 \%(5,2424)$ sedikit di atas mie rehidrasi dari tepung terigu $100 \%(5,0303)$, ini artinya panelis lebih menyukai warna mie kering berbahan baku mocal (S) $40 \%$.

Hasil uji hedonik terhadap mie rehidrasi untuk atribut warna, aroma, rasa kekenyalan dan ekstensibilitas dapat digambarkan dalam bentuk spider chart seperti tercantum pada Gambar 3. Pada Gambar 3 menunjukkan bahwa tingkat kesukaan panelis terhadap mie rehidrasi berbahan baku mocal (S) $40 \%$ yang digambarkan oleh garis berwarna merah dari segi kekenyalan dan ekstensibilitas hampir sama dengan mie rehidrasi dari tepung terigu $100 \%$ yang digambarkan oleh garis kuning. Dari segi aroma kesukaan panelis terhadap mie rehidrasi berbahan baku mocal (S) $40 \%$ sedikit di bawah 
mie rehidrasi dari tepung terigu $100 \%$. Tetapi dari segi warna dan rasa, tingkat kesukaan panelis terhadap mie rehidrasi berbahan baku mocal (S) $40 \%$ sedikit lebih tinggi dibandingkan mie rehidrasi dari tepung terigu $100 \%$.

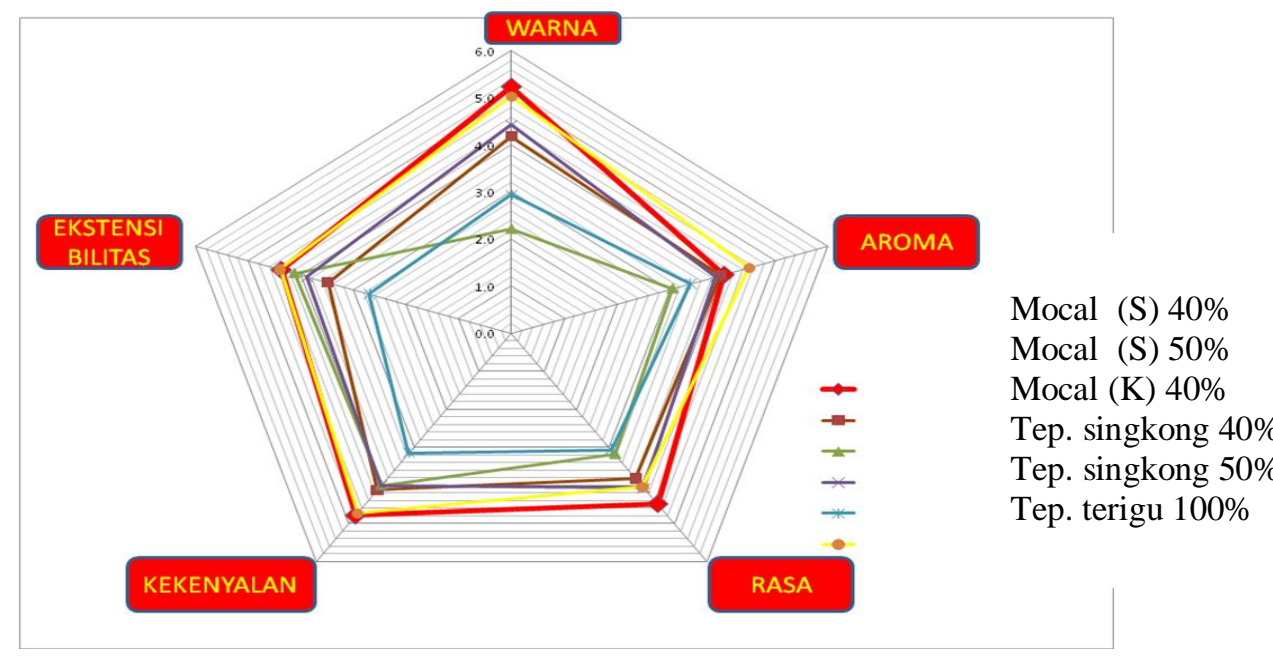

Gambar 3. Spider chart untuk uji hedonik mie rehidrasi

Menurut panelis atribut mutu yang paling penting dalam menilai mie rehidrasi adalah rasa. Sedangkan urutan atribut mutu di bawahnya adalah warna, kekenyalan, aroma dan ekstensibilitas. Dari semua uji organoleptik yang dilakukan, menunjukkan bahwa mie kering yang paling mendekati sifat atau atribut mutu mie kering dari tepung terigu $100 \%$ adalah mie kering dengan komposisi mocal spontan $40 \%$. Mie kering ini kemudian disebut sebagai produk terpilih.

Pada produk mie yang terpilih yakni mie kering dengan komposisi mocal $40 \%$ dilakukan uji komposisi kimia meliputi kadar air, abu, lemak, protein dan serat kasar. Parameter uji secara kimiawi ini mengacu pada SNI mie kering yakni SNI No. 01-29741996.

Hasil uji kimiawi sampel mie kering yang terpilih menunjukkan mie kering dengan bahan baku tepung mocal (S) 40\% memiliki kadar air, abu, protein, lemak dan serat kasar berdasarkan bobot basah berturut-turut adalah 12,31 \%, 3,97 \%, 6,69 \%, 1,13\% dan 3,86\%. Adanya sedikit perbedaan dengan standar SNI 01-2974-1996 mie kering, misalnya untuk kadar air produk, menurut SNI adalah maksimal $10 \%$ untuk mutu II kemungkinan dipengaruhi oleh waktu dan lama proses pengeringan mie kering di dalam oven, dimana suhu yang digunakan untuk pengeringan kurang stabil karena tidak adanya kontrol suhu pada oven. Dari hasil pengujian ini perlu kajian lebih lanjut lagi mengenai formulasi maupun proses pembuatannya sehingga dapat dihasilkan mie kering dengan komposisi kimia sesuai dengan SNI mie kering yakni SNI No. 01-2974-1996. 
Tabel 9. Syarat mutu mie kering berdasarkan SNI No. 01-2974-1996*)

\begin{tabular}{|c|c|c|c|c|}
\hline \multirow{2}{*}{ No. } & \multirow{2}{*}{ Jenis Uji } & \multirow{2}{*}{ Satuan } & \multicolumn{2}{|c|}{ Persyaratan } \\
\hline & & & Mutu I & Mutu II \\
\hline \multirow[t]{4}{*}{1.} & Keadaan & & & \\
\hline & $\mathrm{Bau}$ & - & Normal & Normal \\
\hline & Warna & - & Normal & Normal \\
\hline & Rasa & - & Normal & Normal \\
\hline 2. & Air & $\% \mathrm{~b} / \mathrm{b}$ & Maks. 8 & Maks.10 \\
\hline 3. & Protein (N x 6,25) & $\% \mathrm{~b} / \mathrm{b}$ & Min. 11 & Min.8 \\
\hline 4. & $\begin{array}{l}\text { Bahan Tambahan Makanan } \\
\text { Boraks } \\
\text { Pewarna makanan }\end{array}$ & & \multicolumn{2}{|c|}{$\begin{array}{l}\text { Tidak boleh ada sesuai dengan SNI- } \\
\text { 0222-1995 }\end{array}$} \\
\hline \multirow[t]{5}{*}{5.} & Cemaran logam & & & \\
\hline & Timbal (Pb) & $\mathrm{mg} / \mathrm{kg}$ & Maks. 1,0 & Maks. 1,0 \\
\hline & Tembaga (Cu) & $\mathrm{mg} / \mathrm{kg}$ & Maks. 10,0 & Maks. 10,0 \\
\hline & Seng $(Z n)$ & $\mathrm{mg} / \mathrm{kg}$ & Maks. 40,0 & Maks. 40,0 \\
\hline & Raksa $(\mathrm{Hg})$ & $\mathrm{mg} / \mathrm{kg}$ & Maks. 0,05 & Maks. 0,05 \\
\hline 6. & Arsen (As) & $\mathrm{mg} / \mathrm{kg}$ & Maks.0,5 & Maks. 0,5 \\
\hline \multirow[t]{4}{*}{7.} & Cemaran mikroba & & & \\
\hline & Angka Lempeng Total & koloni/g & Maks. $1,0 \times 10^{6}$ & Maks. $1,0 \times 10^{6}$ \\
\hline & E.coli & $\mathrm{APM} / \mathrm{g}$ & Maks. 10 & Maks. 10 \\
\hline & Kapang & koloni/g & Maks. $1,0 \times 10^{4}$ & Maks. $1,0 \times 10^{4}$ \\
\hline
\end{tabular}

\section{SIMPULAN}

Formula mie kering dengan komposisi mocal $40 \%$ dan tepung terigu $60 \%$ dengan fermentasi spontan merupakan formula terbaik yang memiliki karakteristik mendekati mie kering dari tepung terigu $100 \%$. Menurut panelis atribut mutu yang paling penting dalam menilai mie rehidrasi adalah rasa, sedangkan urutan atribut mutu di bawahnya adalah warna, kekenyalan, aroma dan ekstensibilitas.

Hasil uji kimiawi sampel mie kering yang terpilih menunjukkan mie kering dengan bahan baku tepung mocal $40 \%$ memiliki kadar air, abu, protein, lemak dan serat kasar berdasarkan bobot basah berturut-turut adalah $12,31 \%, 3,97 \%, 6,69 \%, 1,13 \%$ dan $3,86 \%$.

\section{DAFTAR PUSTAKA}

Abidin, A.Z. 2009. Mie Basah Berbahan Dasar Tepung Singkong Pengembangan Formulasi, Proses Produksi dan Karakterisasi Produk. Seminar Nasional Teknik Kimia Indonesia - SNTKI. Bandung, 19-20 Oktober.

Anonim.2009. TentangMocalhttp://www.kebunsingkong.blogspot.com/2009/04/ membuat mie pangsit dengan tepung.html. [Maret 2010]

Badan Standarisasi Nasional. 1994. Standar Nasional Mi Kering No. 01-2974-1996. BSN. Jakarta.

Hidayat, Beni. 2008. Pengembangan Formulasi Produk Mie Berbahan Baku Pati Ubi Kayu. Prosiding Seminar Nasional Sains dan Teknologi - II. Universitas Lampung, 17-18 November. 
Salminen, S. dan A. Von Wright. 1993. Lactic Acid Bacteria. Marcell Dekker, Inc. New York.

Subagio, Achmad. 2009. Penemu Modifikasi Tepung Gaplek. Jawa Pos, 12 Januari.

Suyanti. 2010. Membuat Mie Sehat. Penebar Swadaya. Jakarta.

Yuyun, A. 2008. Panduan Membuat dan Menjual Aneka Mi. Agro Media Pustaka. Jakarta. 